\title{
How far is FDI relevant to India's foreign trade growth? An empirical investigation
}

\author{
Shib Sankar Jana ${ }^{1}$, Tarak Nath Sahu ${ }^{2^{*}}$ and Krishna Dayal Pandey ${ }^{3}$
}

*Correspondence:

taraknathsahu1982@gmail. com

${ }^{2}$ Department of Commerce, Vidyasagar University,

Midnapore, West Bengal 721 102, India

Full list of author information is available at the end of the article

\begin{abstract}
The study seeks to foster fresh empirical evidence on how FDI is relevant to the foreign trade growth in India under a time-varying parameter model with vector autoregressive specification. The Johansen's cointegration test documents a significant and positive long-run co-movement between FDI and foreign trade in India. The vector error correction model suggests a unidirectional long-run causality from foreign trade to FDI. However, the Granger causality test confirms a bidirectional short-run causal relationship between these variables. Further, the variance decomposition analysis approves strong exogeneity of foreign trade. Again, the impulse response function analysis reveals that the responses generated from a positive shock of foreign trade to FDI and vice versa are small and initially negative and thereafter remain persistently positive at a constant level. The study finally concludes that the absence of long-run causality from FDI to export is the result of much domestic market orientation of foreign investors and less emphasis on the export-oriented sectors in India.
\end{abstract}

Keywords: Foreign direct investment, Foreign trade, Export, Vector autoregressive specification

JEL Classification: F13, F14, F21, C22

\section{Introduction}

The World Development Report (World Bank 1987) outlines a crucial observation, that is, while average annual economic growth rate of the Four Asian Tigers, namely Hong Kong, Singapore, South Korea and Taiwan, adopting export-led growth strategy was at $9.5 \%$ during the period of $1963-1973$, it was only $4.1 \%$ in the countries which followed the import-substitution industrialization (ISI) strategy. With the same ISI strategy, India has also witnessed an average economic growth of only around 3.5\% (famously known as the Hindu growth rate) during the 1950s to 1980s. In fact, at the time, the approach to solve economic crises like low growth rate, huge Current Account Deficit (CAD) was still inward. Besides, all the efforts undertaken to solve this were through India's own 'resources and ingenuity' (Economic Survey 1991-1992). Of late, the country's policymakers begun to realize the impact of adopting free-market and outwardoriented trade policies considering the remarkable growth attained by the East Asian tigers who became independent concurrently with India. Witnessing the economic success achieved by the East Asian tigers, the neo-classical economists also begun to rely 
on the doctrine of export-led growth. Notably, the Indian policymakers have learned a lesson on how these economies have utilized the necessary infrastructure and international linkage developed by the colonial government (Gulati 1992) in executing their export-oriented industrialization strategy. In the subsequent period, India, by gradually liberalizing various trading barriers and accepting the idea of export-led economic growth, managed to attain an average annual growth rate of around 5\% for the period of 1981 to 1991. Concurrently, the development economists and academicians worldwide like Feder (1982), Krueger (1990) and Trost and Bojnec (2016) have accepted the exportled economic growth hypothesis. However, despite profound effects on the economic growth and foreign trading status witnessed by other emerging and emerged economies, the concept of FDI-led economic growth has still remained ambiguous and vexing for the Indian policymakers until 1993-1994. Although 'swadeshi spirit', an ideology which endorses the use of domestic products, self-dependency and sufficiency, approves domestic competition and even embraces free trading, foreign investment still remains a question (Jhunjhunwala 2002). Therefore, for the Indian government, the inward-FDI liberalization was a stronger challenge than that of foreign trade liberalization.

Looking at the theoretical and empirical perspective we observe that Harrison (1996) in general perspective views FDI to stimulate exports from domestic sectors through industrial linkage or spill-over effects which further instigates high-demand stimulus for domestic enterprises and results in export promotion. FDI is also believed to enhance export-oriented productivity which further improves export performance (Jana et al. 2017 and Sahu and Pandey 2018). There is a widely accepted view that FDI promotes exports of the host country by augmenting domestic capital for exports, enabling the transfer of technology and production of new products, facilitating access to new and large foreign markets, and providing training for the local workforce to enhance technical and managerial skills (Zhang 2005). However, the outflow of FDI from the home country to the host country largely depends on how strong collaboration the two countries establish with each other to ensure better information flow and coordination relating to the execution of investment projects (Rasiah et al. 2010). According to Narula and Dunning (2000), outward FDI is also much driven by three factors, i.e., efficiency seeking, market seeking and resource seeking from the part of the home country.

Again coming to the Indian perspective we observe that, as of now, economic growth through free trading and allowing inward foreign investment has become an integral part of India's national economic policy. Now, for the Indian government the liberalization of inward FDI policies has two broad objectives: to supplement its export promotion efforts and to promote its economic growth.

To sum up, unlike most of the emerged and emerging market economies, the perception toward FDI-led economic growth reasonably remains susceptive for India. This might be the reason why the economic policies of India pertaining to FDI could not become smooth. Lack of confidence, suspicion and great caution always prevail among the development economists and policymakers over the actual impact of FDI on the Indian economy. In this backdrop, the motivation behind this empirical investigation is routed to the felt need of some fresh empirical insights especially in the context of an emerging economy like Indian where the nexus between FDI and foreign trade is yet not anonymously established. There is a genuine lack of empirical evidence and an economic 
model that can exhibit the actual channel of linkage between these two macro-economic variables. In India, where the policymakers are in a way much concerned about exportled economic growth through liberalized foreign trade, establishing Special Economic Zones (SEZs), Export Processing Zones (EPZs) and in other way are gradually dismantling economic restrictions and consequently deregulating or liberalizing inward foreign investment, an empirical inquiry on the overall economic benefits of inward FDI especially in export promotion is worthwhile to carry out.

\section{Literature review}

For last couple of decades, the understanding of the empirical relationship between the extent of foreign capital inflow especially in the form of FDI and the economic wellbeing of a country in many forms like growth in domestic production, industrial growth, employment generation and foreign trade especially export promotion has really been a core interest for the academicians and economic analysts in India and abroad. The theoretical postulations highlighting the importance of the above-mentioned issues are highly controversial and conflicting and different empirical investigations also identify the ambiguous relationship between these macroeconomic variables. However, the association between these variables is largely country-specific. Moreover, a number of studies have been done during the last few decades to establish the validity of the nexus between FDI and foreign trade promotion.

Zhang (2005) in the context of the Chinese economy shows how FDI plays a significant role in China's export boom. According to the study, its effect is much larger than that of domestic capital and the effect is also momentous in labor-intensive industries in China. The findings of this study is somewhat endorsed by Li et al. (2017) who use the rolling window causality test to understand the dynamic causal relationship between these two macroeconomic variables and finds a significant effects of FDI on exports, mostly during the periods when the proportion of FDI from Hong Kong, Macao and Taiwan is increasing. In a contemporary study, Hsiao and Hsiao (2006) in context of eight rapidly developing East and South-East Asian economies (China, Korea, Taiwan, Hong Kong, Singapore, Malaysia, Philippines and Thailand) suggest that FDI has a unidirectional and direct effect on GDP and also indirect effect through export. Further, Uddin and Habib (2009) in the context of Bangladesh show how there exists a positive cointegrating relationship between FDI and export of this country. The investigation of Harding and Javorcik (2011) also suggests that the inflows of FDI offer the potential for raising the quality of export in developing countries. Haq (2013) also finds statistically significant evidence of a positive impact of FDI on export in Pakistan. A number of other studies like Kugler (2006), Samsu et al. (2009), Enimola (2011) and Bhatt (2013) also find a positive long-run relationship between FDI and foreign trade in the form of export in different countries perspective. Moreover, the study of Bojnec and Ferto (2014) makes a unique focus and identify whether outward FDI serves as a substitute or complementary to merchandise exports. The study finds outward FDI to be a substitute for bilateral merchandise exports and thereby negatively associated with the same between the European OECD countries and EU OECD countries.

On the contrary, a section of literature rather endorses the effect of export on FDI inflows. The advocates of export-led FDI generally argue that export leads to an increase 
in productivity that further attracts foreign investors to undertake FDIs. According to Jun and Singh (1996), the export orientation of the host country can stimulate inward FDI. The study of Mainkhel et al. (2009) on several Latin American countries like Mexico and Chili reveals how in the long-run export affects the FDI inflows. In a different note, by applying Granger causality test Keho (2015) also shows how in long run the volume of exports significantly influences the inflow of FDI in Benin of Africa. Mahmoodi and Mahmoodi (2016) in the context of developing European and Asian panel establish a unidirectional causality from export to FDI in the long run for both panels, but in the short-run European panel evidenced a unidirectional causality from FDI to export.

Besides, there is empirical evidence that suggests the presence of a bidirection relationship between FDI and export in various developed and developing economies. Andersen and Hainaut (1998) indicate that there exists a bidirectional causal link, i.e., exports stimulate FDI inflows and FDI inflows promote exports for the USA, Japan and Germany. Pfaffermayar (1996) conducts a study on Austrian FDI and exports and obtain positive significant causation in both directions. Again, a strong bidirectional FDIexport relation in China is reported by Liu et al. (2002). Other empirical studies like Pacheco-Lopez (2005) in the context of Mexico, Zhang and Felmingham (2001) in the People Republic China, and Keho (2015) on sub-Saharan African countries document a bidirectional causal link between FDI and foreign trade in the form of export.

Putting India into perspective, the studies on the relation between FDI and export is very limited in number and the findings of the literature are providing mixed evidence. Prasanna (2010) advocates inward FDI to have a significant contribution toward magnifying the export performance of India between 1991-1992 and 2006-2007. Similarly, Barua (2013) argues that FDI in India may complement local developmental efforts by boosting export competitiveness and acts as a vehicle for accelerating the pace of export. On the contrary, in a contemporary study, Dash and Sharma (2011) find a unidirectional causality between FDI and export where it runs from the later to the former. Again, Sultan (2013) finds a similar result as observed by Dash and Sharma (2011) applying Johansen cointegration method and VECM. However, Chakraborty et al. (2016) observe FDI inflows to be non-contributive to exports, while reverse relation is true, underlining the fact that FDI inflows in the country may mostly be targeting the growing domestic sectors, rather than utilizing domestic resources for reaching the global market. Other studies like Sharma (2000) and Singh and Tandon (2015) cannot establish any significant statistical association between the variables.

\subsection{Research gap}

It is observed from the above review that the findings relating to FDI-foreign trade nexus are heterogeneous. The heterogeneity in the results is basically due to the difference in economic and legal framework and time period considered in the studies. Therefore, the inferences drawn in the existing set of studies cannot be generalized for policy prescriptions. Thus, the dynamic relationship between FDI and foreign trade needs to be examined and understood with changing economic and legal scenarios. Another notable observation from the review of literature is that most of the studies lack stringent and penetrating examination which might ensure greater stability and robustness in the statistical estimations. Addressing this issue, the present study employs a number 
of stringent econometric estimations like Impulse Response Function, Variance Decomposition and KUSUM test along with a relevant set of diagnostic tests to ensure robust findings and reliable inferences.

It is also sensible to assume that the previous literature cannot produce the recent picture on the FDI-foreign trade nexus because the economic policies relating to both are rapidly altering with shifting political ideologies in the country and changing dynamics of the international business environment. The recent changes in FDI and foreign trading policy measures need to be encountered while modeling the statistical association between these variables.

\subsection{Objectives of the study}

In the backdrop of the above discussion, the present study is carried out with the following objectives:

1. To examine empirically the association between foreign direct investment and foreign trade promotion in the terms of export in the context of the Indian economy.

2. To provide recommendations to the concerned policymakers.

\section{Data and methodology}

To establish the dynamic relationship between FDI and foreign trade, the study uses secondary data during the period from the 1st quarter of 1996-1997 to the 4th quarter of 2018-2019 (92 observations). The study actually focuses on the post-liberalization period but owing to the fact that the considerable effect of economic liberalization initiated in the year 1991-1992 seems to appear in different macro-economic factors including inward FDI and foreign trading since mid-nineties. In this study, foreign trade is represented by the volume of export of India. The monthly data of FDI and export are collected and composed from various issues of Handbook of Statistics on the Indian Economy and Reserve Bank of India Bulletins, published by Reserve Bank of India and thereafter the collected data are cumulated as quarterly form. Moreover, it is noteworthy that our analysis mainly involves the establishment of a causal relationship between FDI and export in the context of India. Therefore, it is sensible to assume that taking them in the constant or current prices would not make any significant difference in the statistical estimation. Adjustment of inflation in case of constant pricing method would impact both the variables in a similar way and therefore would not alter the causal association between them. Based on this view, the study considers both the variables in their current prices.

The study first determines the descriptive statistics to know the basic characteristics of the variables used in the analysis and estimates unit root test to check whether the data series is stationary or non-stationary. This would help us in applying the cointegration test, Vector Error Correction Model (VECM), variance decomposition test and impulse response analysis to establish the long- and short-run dynamic relationship between the variables and Granger causality test to identify the direction of causality.

To investigate the long-run equilibrium relationship, the stationarity of a data series is a prerequisite in a time series analysis for drawing meaningful inference and to enhance 
the accuracy and reliability of the models constructed. The stationarity property and the order of integration of the variables are the two important preconditions for applying either regression models or cointegration techniques which are popularly checked by the unit root test. Data with incorrect order of integration lead to spurious regression estimates or wrong test statistics which further makes the analysis useless. Among a large number of prevalent unit root tests, the study introduces the two most popular and commonly used tests namely the Augmented Dickey-Fuller (ADF) test and Phillips-Perron (PP) test (Sahu et al. 2013 and Sahu and Pandey 2020).

The selection of appropriate lag length is a sensitive and decisive factor in the autoregressive model. Therefore, the appropriate lag length needs to be determined prior to estimation. There is no commonly agreed technique to select the lags and variables' structure; however, the outcome of the estimation heavily depends on the selection of appropriate lag length. The study determines the optimum lag length based on the Akaike Information Criteria (AIC), Schwarz Information Criteria (SIC) and HannanQuinn Information Criteria (HQC).

To ascertain the long-run relationship between the flow of FDI and foreign trade, the study employs the VAR (Vector Autoregression)-based approach of the cointegration test suggested by Johansen (1988). In this approach of cointegration test, Trace test (or Likelihood ratio test), as well as Maximum Eigen value test, is applied to decipher the stated long-term dynamics. This test is based on the following vector autoregressive model.

$$
Y_{t}=\mu+A_{1} Y_{t-1}+A_{2} Y_{t-2}+A_{3} Y_{t-3}+\cdots+A_{p} Y_{t-p}+u_{t},
$$

where $Y_{t}$ is a vector containing $n$ variables, all of which are integrated of order 1 and the subscript $\mathrm{t}$ denotes the time period. $\mu$ is an $(n \times 1)$ vector of constants, $A_{p}$ is an $(n \times n)$ matrix of coefficient where $p$ is the maximum lag included in the model and $u_{t}$ is an $(n \times 1)$ vector of error terms. This can be written in the form of the error correction framework. The previous VAR can be written as

$$
\Delta Y_{t}=\mu+\Pi Y_{t-p}+\Gamma_{1} \Delta Y_{t-1}+\Gamma_{2} \Delta Y_{t-2}+\cdots+\Gamma_{p-1} \Delta Y_{t-p+1}+u_{t},
$$

where $\Gamma_{i}=-\sum_{j=i+1}^{p} A_{j}$ represents the dynamics of the model in the short run and $\Pi=\sum_{i=1}^{p} A_{i}-I$ represents the long-run relationship among the variables included in the vector $Y_{t}$, and $I$ is the identity vector. The key idea of the Johansen's approach is to determine the rank of the matrix $\Pi$, which represents the number of independent cointegrating vectors. To identify the rank of the matrix $\Pi$, the study uses two test statistics: the Trace test and the Maximum Eigen Value test. The concept of cointegration becomes more relevant when the time series being analyzed is non-stationary in level and all the variables used in the study are in the same order of integration. In econometric terms, two or more variables are said to be cointegrated if they share a common trend. Appropriately, the test provides information on whether the variables are tied together in the long run. The presence of cointegration indicates the interdependence of the endogenous variables.

The results of the long-run and short-run relationships between two or more variables do not always coincide. There often exists a long-run equilibrium relationship between two or more variables but in the short run, there may be disequilibrium. The nature of 
the relationship between FDI and foreign trade in the short run can be explored by considering the Vector Error Correction Mechanism. A vector error correction model is a restricted VAR that has cointegration restrictions built into the specification so that it is designed for use with non-stationary series that are known to be cointegrated. The error correction term of VECM specification indicates the rate at which it corrects its previous period disequilibrium or speed of adjustment to restore the long-run equilibrium relationship. Thus, the error correction procedure is a way to reconcile short-run and long-run behavior through a series of partial short-run adjustments. More precisely, in a two-variable setting where $X$ and $Y$ are integrated of order 1 or $I(1)$, the vector error correction model can be formulated as

$$
\begin{aligned}
& \Delta X_{t}=\delta_{i}+\sum_{i=1}^{p} \alpha_{i} \Delta X_{t-i}+\sum_{i=1}^{p} \beta_{i} \Delta Y_{t-i}+\gamma_{1} \hat{\varepsilon}_{1 t-1}+u_{1 t} \\
& \Delta Y_{t}=\lambda_{i}+\sum_{i=1}^{p} d_{i} \Delta X_{t-i}+\sum_{i=1}^{p} c_{i} \Delta Y_{t-i}+\gamma_{2} \hat{\varepsilon}_{2 t-1}+u_{2 t}
\end{aligned}
$$

where $\hat{\varepsilon}_{1 t-1}$ and $\hat{\varepsilon}_{2 t-1}$ are the error correction terms obtained from the long-run model, which can be interpreted as the deviation of $X$ and $Y$ from their long-run equilibrium values, respectively. The error correction terms represent the short-run dynamics necessary to reach the long-run equilibrium. The coefficient $\gamma_{i}$ tells us the rate at which it corrects the previous period disequilibrium of the system, i.e., the speed of the adjustment toward the long-run equilibrium relationship. $\beta_{i}$ measures the short-run impact of changes in $Y$ on $X, d_{i}$ measures the short-run impact of changes in $X$ on $Y$, and $u_{i t}$ is the standard error term.

The Granger causality test is introduced to validate the existence and nature of the causal relationship between the variables. It can be estimated in two different ways depending on the results of the long-run analysis. The Granger test (Granger 1969) is suitable for analyzing the short-run causal relationship when no cointegration exists among the variables. On the other hand, when the variables are cointegrated, the standard Granger test is misspecified and the error correction strategy suggested by Engle and Granger (1987) should be used. The study proceeds with a Granger causality test in the form of a vector error correction model, as the variables are found to be cointegrated. VECM allows the modeling of both the short- and long-run dynamics for the variables involved in the model. The error correction term of VECM indicates the direction of long-run causality, whereas the short-run causality among the variables is tested through VEC Granger causality test or Block Exogeneity Wald test.

Although it is highly important to introduce the causality tests, the empirical inferences based on these neither determine the strength of the causality nor the relationship between the variables over time. Moreover, the Granger causality test cannot gage the degree of exogeneity among the variables beyond the sample period. Hence, the variance decomposition test is used to explore the degree of exogeneity of the variables involved in the study. The variance decomposition results show how one variable explains a substantial part of the variation of another variable over time. It also exhibits the proportion of the forecast error of each variable that is accounted for by 
another variable and enables us to determine the relative importance of a variable in generating fluctuations in another variable.

Again, the empirical inferences based on the Granger causality test help to qualify the flow of influences but the estimates of the impulse response analysis give a quantitative idea about the impacts for several periods in the future. The responses of foreign trade to shock in the FDI and vice versa are examined through impulse response function analysis. This will help to get a better understanding of the shortand long-term influences of FDI on foreign trade and vice versa (Sahu 2016). The impulse response function tracks the response of variable over time after a shock to the VAR system. The persistence of the impact of a shock indicates how quickly the system returns to equilibrium. The impulse response function will help to determine the magnitude, direction and length of time that a variable is affected by a shock of another variable in the system, holding all other variables constant.

Finally, the study conducts different diagnostic tests to judge the robustness of the estimated model as well as measures the stability of the model.

\section{Analysis and findings of the study}

\subsection{Findings from the descriptive statistics}

In the first phase of the analysis, the summary statistics provide a historical background for the nature of the data used. The descriptive statistics presented in Table 1 show that the variables are not stable at all during the study period. It is observed that the volumes of foreign trade and FDI have significant variability from their mean values. In respect of FDI, the maximum value of Rs. 942.71 billion and a minimum value of Rs. 142.54 billion are found with an average of Rs. 243.80 billion, signifying its instability during the study period. The high value of the standard deviation in this regard also confirms the instability.

During the study period, the volume of export has also been very high and there is also significant variability from their mean. The high differences between maximum values and minimum values reveal that the volumes of export are highly unstable during this period. However, values of the data series lie within $\bar{X} \pm 3 \sigma$, where, $\bar{X}$ and $\sigma$ represent mean and standard deviation, respectively.

Table 1 Descriptive statistics. Source: Calculated by authors

\begin{tabular}{lcc}
\hline Statistics & FDI & FT \\
\hline Mean & 272.1269 & 2294.188 \\
Median & 199.1603 & 1596.316 \\
Maximum & 952.7000 & 6030.750 \\
Minimum & 13.24542 & 285.5171 \\
Standard deviation & 279.2359 & 1844.559 \\
Skewness & 0.945301 & 0.464470 \\
Kurtosis & 2.811932 & 1.664562 \\
Jarque-Bera test statistics & 13.83736 & 10.14424 \\
Probability & 0.000989 & 0.006269 \\
\hline
\end{tabular}


Table 2 Results of Augmented Dickey-Fuller (ADF) unit root test. Source: Calculated by authors

\begin{tabular}{|c|c|c|c|c|c|}
\hline \multirow[t]{2}{*}{ Variables } & \multicolumn{2}{|l|}{ Level } & \multicolumn{2}{|l|}{ First difference } & \multirow[t]{2}{*}{ Result } \\
\hline & Intercept & Trend and intercept & Intercept & Trend and intercept & \\
\hline FDI & $\begin{array}{l}-0.047034[3] \\
(0.9508)\end{array}$ & $\begin{array}{l}-2.737981[2] \\
(0.2246)\end{array}$ & $\begin{array}{l}-9.576341[2] \\
(0.0000)\end{array}$ & $\begin{array}{l}-9.598985[2] \\
(0.0000)\end{array}$ & $/(1)$ \\
\hline FT & $\begin{array}{l}0.471794[1] \\
(0.9848)\end{array}$ & $\begin{array}{l}-1.971431[1] \\
(0.6081)\end{array}$ & $\begin{array}{l}-12.09500[0] \\
(0.0001)\end{array}$ & $\begin{array}{l}-12.17031[0] \\
(0.0000)\end{array}$ & $/(1)$ \\
\hline
\end{tabular}

() MacKinnon (1996) one-sided $p$ values; [] Lag lengths for ADF Test; /(1): Stationary after first difference

Table 3 Results of Phillips-Perron (PP) unit root test. Source: Calculated by authors

\begin{tabular}{|c|c|c|c|c|c|}
\hline \multirow[t]{2}{*}{ Variables } & \multicolumn{2}{|l|}{ Level } & \multicolumn{2}{|l|}{ First Difference } & \multirow[t]{2}{*}{ Resul } \\
\hline & Intercept & Trend and intercept & Intercept & Trend and intercept & \\
\hline FDI & $\begin{array}{l}-2.272225[3] \\
(0.1833)\end{array}$ & $\begin{array}{l}-4.771338[5] \\
(0.0856)\end{array}$ & $\begin{array}{l}-23.66715[17] \\
(0.0001)\end{array}$ & $\begin{array}{l}-24.78887[18] \\
(0.0001)\end{array}$ & $/(1)$ \\
\hline FT & $\begin{array}{l}0.369675[3] \\
(0.9805)\end{array}$ & $\begin{array}{l}-2.129533[1] \\
(0.5220)\end{array}$ & $\begin{array}{l}-11.94672[2] \\
(0.0001)\end{array}$ & $\begin{array}{l}-12.03251[2] \\
(0.0000)\end{array}$ & $/(1)$ \\
\hline
\end{tabular}

() MacKinnon (1996) one-sided $p$ values; [ Lag lengths for PP Test; /(1): Stationary after first difference

\subsection{Findings from long-run analysis}

As already stated, the long-run analysis is conducted using Johansen's cointegration test. Typically, the Johansen cointegration test consists of three general steps. First, examine whether all variables in the model are integrated of the same order, which can be established by unit root tests. Second, determine the optimal lag length for the VAR model to verify that the estimated residuals are not autocorrelated. Last, estimate the VAR model to construct the cointegration vectors in order to determine the cointegrating relationship. For this, it is necessary to establish the trace and the maximum eigen value statistics tests. The following subsections present the results for each step.

\subsubsection{Results of unit root test}

Testing stationarity of a data series is a prerequisite for drawing meaningful inferences in a time series analysis. It enhances the accuracy and reliability of the models constructed. So, it is necessary to determine the unit root property and order of integration for each variable included in the system. Both the unit root tests as proposed by Dickey-Fuller and Phillips-Perron are performed with intercept and time trend and intercept for all variables in their levels, and then, the tests are performed with their first difference values and so on.

Tables 2 and 3 present the Augmented Dickey-Fuller (ADF) and Phillips-Perron (PP) unit root tests' results of the variables in their level and first difference. From the results presented in the tables, it is clear that the null hypothesis, i.e., the existence of a unit root in its levels cannot be rejected for any of the series since the $t$-statistics of ADF and PP tests of the variables are less than the critical values at any level of significance, i.e., 1 and $5 \%$. Therefore, the unit root test result concludes that all the series are non-stationary in level. Applying the same tests to their first differences shows that the null hypothesis of a unit root is rejected in all cases. So, from the results of ADF test and PP test of FDI and 
Table 4 VAR lag order selection criteria for FDI and FT. Source: Calculated by authors

\begin{tabular}{llcc}
\hline Lag length & AIC & SIC & HQC \\
\hline 0 & 30.36294 & 30.42293 & 30.38697 \\
1 & 26.23736 & 26.41732 & 26.30946 \\
2 & 26.12167 & 26.42160 & 26.24183 \\
3 & 25.79215 & $26.21205^{\mathrm{a}}$ & 25.96037 \\
4 & 25.69656 & 26.23643 & $25.91285^{\mathrm{a}}$ \\
5 & 25.68142 & 26.34127 & 25.94577 \\
6 & 25.76333 & 26.54315 & 26.07575 \\
7 & 25.68274 & 26.58253 & 26.04322 \\
8 & $25.62565^{\mathrm{a}}$ & 26.64541 & 26.03419 \\
\hline a & & &
\end{tabular}

Optimum lag order selected by the criterion

Table 5 Results of Johansen cointegration test (trace statistics) for FDI and FT. Source: Calculated by authors

\begin{tabular}{llccc}
\hline $\boldsymbol{H}_{\mathbf{0}}$ & $\boldsymbol{H}_{\mathbf{1}}$ & Trace statistics & $\mathbf{5 \%}$ critical value & Probability* \\
\hline$r=0$ & $r=1$ & 16.15875 & 15.49471 & 0.0397 \\
$r \leq 1$ & $r=2$ & 1.608256 & 3.841466 & 0.2047 \\
\hline
\end{tabular}

* MacKinnon et al. (1999) $p$ values

foreign trade, in its first difference, for the two models Intercept and Trend and Intercept show that FDI and foreign trade are stationary at their first difference, i.e., the variables are integrated of order 1, i.e., $I(1)$.

\subsubsection{Selection of optimum lag length}

As the autoregressive model is sensitive to the selection of appropriate lag length, the study is to ascertain the appropriate lag length before conducting the cointegration analysis in line with Johansen. The optimum lag length based on the three commonly used criteria, namely AIC, SIC and HQC, is presented in Table 4.

The three lag length selection criteria suggest three different lag lengths as optimum lag. Choosing one among these three criteria is much of a subjective consideration. In this study, we select the optimum lag length as 8 suggested by the AIC criteria. The AIC criterion is considered because it is commonly used and highly accredited in the field of econometrics.

\subsubsection{Results of Johansen cointegration test}

Since FDI and foreign trade have unit root property at their level values and are integrated of order 1, it is highly useful to conduct a cointegration test suggested by Johansen to find out whether these variables have a long-term common stochastic trend.

The calculated values of trace statistics (Table 5) and maximum eigen statistics (Table 6) of Johansen's cointegration test, when the null hypothesis is $r=0$ (i.e., no cointegration), are 15.49 and 14.26, respectively. Here, the null hypothesis of no cointegration when $r=0$ is rejected at $5 \%$ level of significance, as the calculated values of trace statistics and maximum eigen statistics are higher than the MacKinnon-Haug-Michelis critical value at $5 \%$ level of significance. This indicates the existence of a cointegrating 
Table 6 Results of Johansen cointegration test (maximum Eigen statistics) for FDI and FT. Source: Calculated by authors

\begin{tabular}{llccc}
\hline $\boldsymbol{H}_{\mathbf{0}}$ & $\boldsymbol{H}_{\mathbf{1}}$ & $\begin{array}{l}\text { Maximum Eigen } \\
\text { statistics }\end{array}$ & $\mathbf{5 \% \text { critical value }}$ & Probability* \\
\hline$r=0$ & $r=1$ & 14.55049 & 14.26460 & 0.0451 \\
$r \leq 1$ & $r=2$ & 1.608256 & 3.841466 & 0.2047 \\
\hline
\end{tabular}

* MacKinnon et al. (1999) $p$ values

vector between FDI and foreign trade. Thus, the Johansen cointegration test result depicts that FDI and foreign trade are cointegrated and there exists a long-term cointegrating relationship. The long-run cointegrating equation is

$$
\mathrm{FDI}=-73.3851+0.1501 \mathrm{FT}_{[t=10.2646]}+\mu_{t} .
$$

Based on the above cointegrating equations, the study confirms that in long run there is a positive and significant (based on the $t$ test statistics) relationship between FDI and foreign trade, i.e., they move together in the same direction, as the $t$ value associated with the coefficient in each cointegrating equation is significant at $5 \%$ level of significance.

\subsection{Findings from short-run analysis}

Having established that both the variables are cointegrated, the fundamental question that arises regarding the nature of the dynamic relationship between FDI and FT in the short run can be answered by considering the vector error correction mechanism.

\subsubsection{Result of the vector error correction model}

The results of the vector error correction model are presented in Table 7. This table shows that the $t$ values associated with the coefficients of the lag values of foreign trade are found to be statistically significant when FDI is considered as the dependent variable. It indicates that the FT has a significant and positive impact on the flow of FDI. The result also confirms that in the short run the flow of FDI does not have any influence on FT.

The VECM result also indicates that the values of FDI adjust the disturbances to restore long-run equilibrium significantly and in the right direction, but the values of foreign trade do not react significantly. The coefficient of error correction term -0.5597 is significant at $1 \%$ level. This value indicates the rate at which it corrects the disequilibrium of the previous period. Thus, the speed of adjustment toward the long-run equilibrium is about $56 \%$ per quarter.

\subsubsection{Results of diagnostic tests}

To test and ensure the robustness of the results and model specification, the study estimates different diagnostic tests such as serial correlation test, normality test and heteroscedasticity test. The diagnostic test results are presented in Table 8. The result of the serial correlation test, conducted through the Lagrange-Multiplier test of residuals, clearly indicates that the residuals of VECM estimations between FDI and FT are not serially correlated, as the underlying null hypothesis of 'no serial correlation in the residuals' cannot be rejected. 
Table 7 Results of vector error correction model for FDI and FT. Source: Calculated by authors

\begin{tabular}{|c|c|c|}
\hline \multirow[t]{2}{*}{ Independent variables } & \multicolumn{2}{|c|}{ Dependent variables } \\
\hline & $\mathrm{D}(\mathrm{FDI})$ & $\mathrm{D}(\mathrm{FT})$ \\
\hline $\mathrm{ECT}\left(\gamma_{1}\right)$ & $\begin{array}{l}-0.559680^{* *} \\
{[-3.53137]}\end{array}$ & $\begin{array}{l}-0.059786 \\
{[-0.19393]}\end{array}$ \\
\hline $\mathrm{D}(\mathrm{FDI}(-1))$ & $\begin{array}{l}-0.306610 \\
{[-1.84242]}\end{array}$ & $\begin{array}{r}0.230862 \\
{[0.71319]}\end{array}$ \\
\hline $\mathrm{D}(\mathrm{FDI}(-2))$ & $\begin{array}{l}-0.468589^{* *} \\
{[-2.77988]}\end{array}$ & $\begin{array}{r}0.167045 \\
{[0.50947]}\end{array}$ \\
\hline $\mathrm{D}(\mathrm{FDI}(-3))$ & $\begin{array}{l}-0.177300 \\
{[-1.00416]}\end{array}$ & $\begin{array}{l}0.550672 \\
{[1.47688]}\end{array}$ \\
\hline $\mathrm{D}(\mathrm{FDI}(-4)$ & $\begin{array}{r}0.020871 \\
{[0.11060]}\end{array}$ & $\begin{array}{l}-0.662191 \\
{[-1.80401]}\end{array}$ \\
\hline $\mathrm{D}(\mathrm{FDI}(-5))$ & $\begin{array}{r}0.269567 \\
{[1.46698]}\end{array}$ & $\begin{array}{l}-0.421394 \\
{[-1.17894]}\end{array}$ \\
\hline $\mathrm{D}(\mathrm{FDI}(-6))$ & $\begin{array}{r}0.307804 \\
{[1.88480]}\end{array}$ & $\begin{array}{l}-0.474188 \\
{[-1.49276]}\end{array}$ \\
\hline $\mathrm{D}(\mathrm{FDI}(-7))$ & $\begin{array}{l}0.433934^{* *} \\
{[3.11513]}\end{array}$ & $\begin{array}{c}0.247188 \\
{[0.91228]}\end{array}$ \\
\hline $\mathrm{D}(\mathrm{FT}(-1))$ & $\begin{array}{l}-0.059877 \\
{[-0.87943]}\end{array}$ & $\begin{array}{l}-0.179147 \\
{[-1.35269]}\end{array}$ \\
\hline $\mathrm{D}(\mathrm{FT}(-2))$ & $\begin{array}{l}0.142726^{*} \\
{[2.19310]}\end{array}$ & $\begin{array}{c}0.169896 \\
{[1.34211]}\end{array}$ \\
\hline $\mathrm{D}(\mathrm{FT}(-3))$ & $\begin{array}{l}0.193774^{* *} \\
{[2.86742]}\end{array}$ & $\begin{array}{l}-0.065016 \\
{[-0.49461}\end{array}$ \\
\hline $\mathrm{D}(\mathrm{FT}(-4))$ & $\begin{array}{l}-0.093738 \\
{[-1.30140]}\end{array}$ & $\begin{array}{c}0.237515 \\
{[1.69525]}\end{array}$ \\
\hline $\mathrm{D}(\mathrm{FT}(-5))$ & $\begin{array}{l}-0.098020 \\
{[-1.30814]}\end{array}$ & $\begin{array}{r}0.005169 \\
{[0.03546]}\end{array}$ \\
\hline $\mathrm{D}(\mathrm{FT}(-6))$ & $\begin{array}{l}-0.097403 \\
{[-1.42061}\end{array}$ & $\begin{array}{l}-0.216399 \\
{[-1.62258]}\end{array}$ \\
\hline $\mathrm{D}(\mathrm{FT}(-7))$ & $\begin{array}{l}-0.045981 \\
{[-0.66492]}\end{array}$ & $\begin{array}{l}-0.098890 \\
{[-0.73517]}\end{array}$ \\
\hline C & $\begin{array}{r}29.59317 \\
{[1.78044]}\end{array}$ & $\begin{array}{l}80.43425^{*} \\
{[2.48785]}\end{array}$ \\
\hline
\end{tabular}

** Statistically significant at $1 \%$ level; * statistically significant at $5 \%$ level; []$t$ values

Table 8 Diagnostic tests results. Source: Calculated by authors

\begin{tabular}{llll}
\hline VEC residual of & Serial correlation (A) & Normality (B) & Heteroscedasticity (C) \\
\hline FDl and FT & 1.333034 & 41.07028 & 68.62615 \\
& $(0.2505)$ & $(0.0000)$ & $(0.3884)$ \\
\hline
\end{tabular}

(A) Based on Lagrange Multiplier Test of Residual Serial Correlation

(B) Based on a test of Skewness and Kurtosis of Residuals (Jarque-Bera test of Normality)

(C) Based on the White Heteroscedasticity Test with no Cross Terms Yields

() Respective probability values are presented in parentheses

Again the results disclosed in the last column of Table 8 reveal that the model is free from heteroscedasticity problems. Similarly, the results of the Jurque-Bera test suggest that the model residuals are normal.

To test the stability of the estimated coefficients, the study applies cumulative sum of recursive residuals (CUSUM). The results of the CUSUM test depicted in Fig. 1 


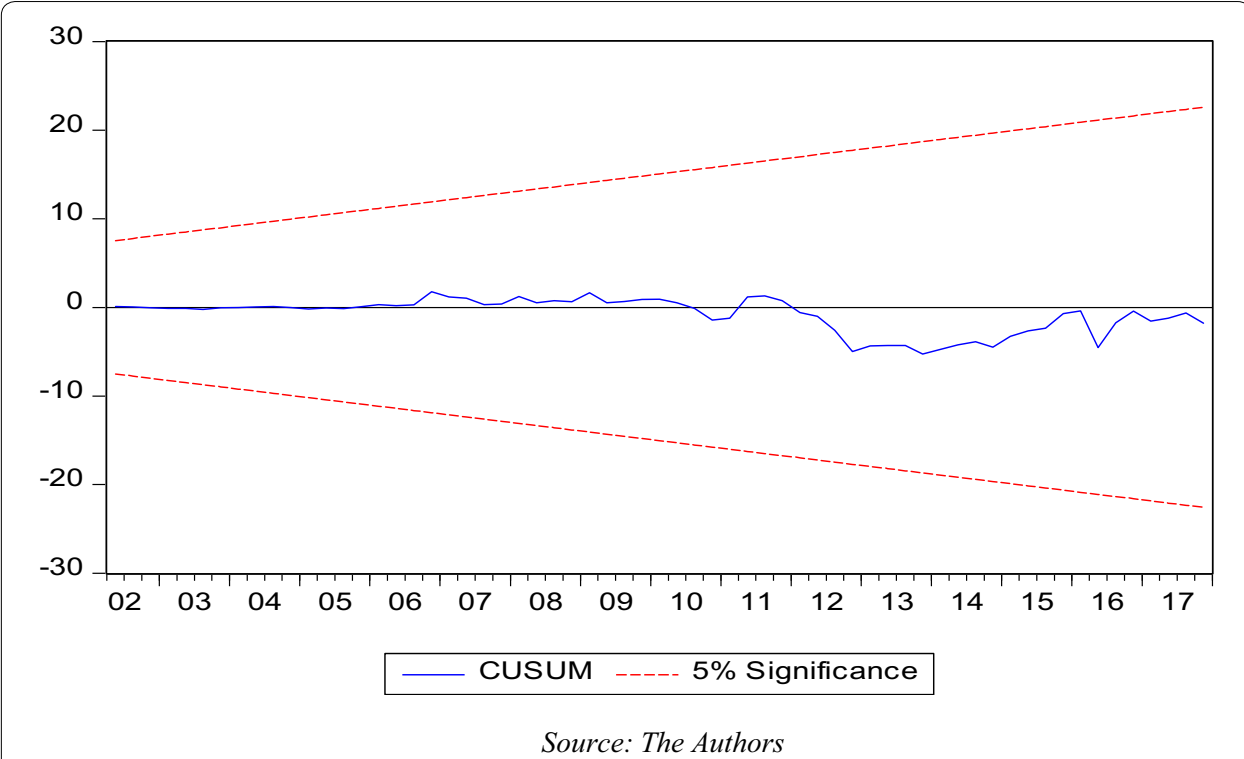

Fig. 1 Plot of cumulative sum of recursive residuals for FDI and FT

suggest that at $5 \%$ level of significance the parameters of the model are stable over the period of the study. So, this part of the investigation ensures the acceptability of the model and the robustness of the results.

\subsection{Findings from causality test}

As the variables are cointegrated, the standard Granger test is misspecified and the error correction strategy suggested by Engle and Granger (1987) is used to identify the long- and short-run causal relationship among the variables. The results of the long-run and the short-run causality tests under VECM framework are reported below:

\subsubsection{Long-run causality}

In Table 7, the $t$ values associated with the error correction terms of VECM suggest the existence of significant unidirectional long-run causality. The coefficient of the error correction term -0.5597 is found to be statistically significant at $1 \%$ level which indicates that any change in the value of foreign trade causes changes in the flow of FDI in the long run. But in long run change in FDI flow does not have any causal effect on foreign trade.

\subsubsection{Short-run causality}

The results of the short-run causality test among the variables based on the VEC Granger causality test are presented in Table 9.

According to the obtained results, it can be documented that there is a bidirectional short-run causal relationship between FDI and foreign trade, i.e., in the short run the volume of foreign trade significantly affects the flow of FDI and vice versa. 
Table 9 Result of VEC Granger causality/block exogeneity Wald test for FDI and FT. Source: Calculated by authors

\begin{tabular}{lllll}
\hline $\begin{array}{l}\text { Dependent } \\
\text { variables }\end{array}$ & $\begin{array}{l}\text { Independent } \\
\text { variables }\end{array}$ & Chi square value & Probability value & Implication \\
\hline FT & FDI & 24.75064 & 0.0008 & Causality exists \\
FDI & FT & 28.63891 & 0.0002 & Causality exists \\
\hline
\end{tabular}

Table 10 Variance decomposition of FT and FDI. Source: Calculated by authors

\begin{tabular}{lccc}
\hline Variance decompositions of & Period & \multicolumn{2}{l}{$\begin{array}{l}\text { Percentage of forecast error variance } \\
\text { explained by innovation in }\end{array}$} \\
\cline { 3 - 4 } & & FDI & FT \\
\hline FDI & 1 & 100.0000 & 0.000000 \\
& 4 & 82.37717 & 17.62283 \\
& 8 & 83.35161 & 16.64839 \\
& 12 & 77.09287 & 22.90713 \\
& 16 & 68.65137 & 31.34863 \\
& 20 & 63.11129 & 36.88871 \\
& 1 & 0.840561 & 99.15944 \\
& 4 & 7.978812 & 92.02119 \\
& 8 & 10.23082 & 89.76918 \\
& 12 & 10.25639 & 89.74361 \\
& 16 & 9.089965 & 90.91004 \\
& 20 & 8.221961 & 91.77804 \\
\hline
\end{tabular}

\subsection{Results of variance decomposition test and impulse response function analysis}

The study estimates the variance decomposition and impulse response function under the VECM framework to investigate the dynamic relationship between the flow of FDI and the volume of FT in India.

Table 10 indicates that foreign trade is strongly exogenous because more than $91 \%$ of its variances is explained by its own shocks even after 20 quarters, i.e., 5 years and in this way, shock in the foreign trade itself remains the main driver behind its movement, while the explanatory power of FDI is found insignificant. A very small portion of the forecast error variance of foreign trade is explained by FDI. This is due to the fact that during the study period the values of FT are more dependent on themselves than on the FDI inflows. The results also indicate that the values of FDI are less exogenous than FT in the sense that the percentage of the error variance of FDI accounted by its own shock is approximately $63 \%$ at a time horizon of 20 quarters. Here, more than $36 \%$ of error variance of FDI is explained by FT at the said time horizon.

The results of the impulse response analysis for a time horizon of 20 quarters to a one standard deviation shock in FT and FDI are shown in Fig. 2. The responses generated from a positive shock of FT to FDI are very small. The responses are initially negative for a very small period of time and thereafter remain consistently positive. However, the responses in the reverse case, i.e., for a positive shock of FDI to FT are found to be comparatively higher. The responses are again found to be negative for a short time span and thereafter these remain persistently positive at a constant level. 


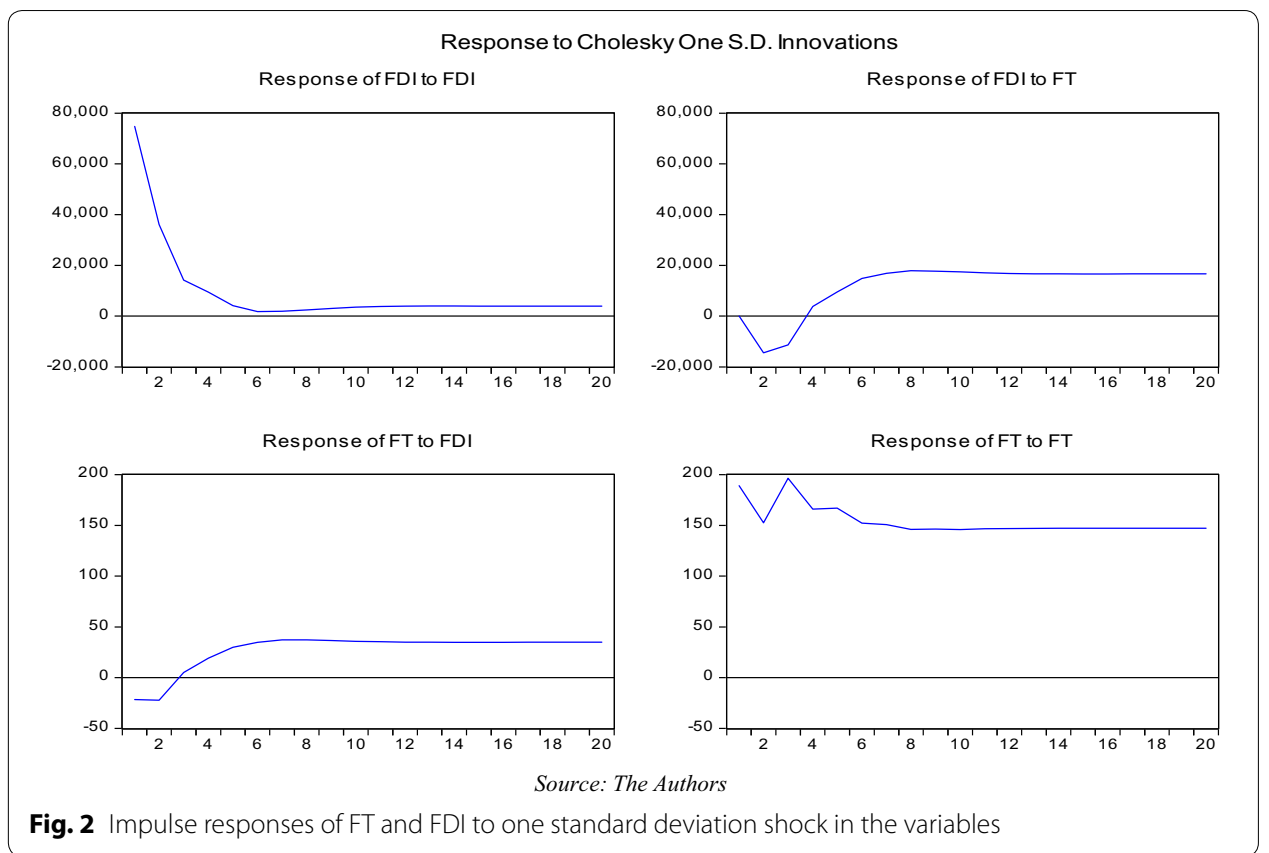

\section{Empirical results and discussion}

The study uses Johansen's cointegration test and documents a significant and positive long-run co-movement between foreign direct investment and foreign trade in India. The vector error correction model establishes a unidirectional long-run causality, flowing from foreign trade to foreign direct investment where the Granger causality test documents a bidirectional short-run causality between these variables. Further, the variance decomposition analysis confirms the strong exogeneity of foreign trade, showing that the large proportion of its variances is explained by its own shocks even after a time lag of 20 quarters while the explanatory power of FDI is found insignificant. Again the impulse response function analysis shows that the responses generated from a positive shock of foreign trade to FDI and vice versa are small and initially negative for a very short time period and thereafter both of these remain persistently positive at a more or less constant level. The findings of this study are aligned with the studies carried out by Dash and Sharma (2011) and Sultan (2013) which find a long-run unidirectional causality from export to FDI. However, on the contrary, the study of Prasanna (2010) which finds FDI to have a significant long-run impact on export performance does not move with the line of this study. Again, being somewhat at odds with this study, Kishore (2012) and Sing and Tandon (2015) document no significant statistical association between the variables.

On the other side, the existence of bidirectional short-run causality between FDI and export is crucial evidence of this study. Thus, although the time span is short, FDI seems to have the potential to promote the export of the country. The existence of bidirectional causality is due to the fact that the foreign investors are coming with the anticipation of reaping up the advantage of growing export orientation of the government in the form of establishment of Special Economic Zones and Export Processing 
Zones, launching of Service Export from India Scheme (SEIS) and Merchandise Export from India Scheme (MEIS), etc. The Government's growing concern over export promotion indicates the opportunities for foreign investors to export their products and services in the attractive global market by utilizing the huge natural and human resources of the host country. In short run, this huge inward flow of foreign funds elevates the export performance which again attracts more FDI. In this way, FDI and export are reinforcing each other for a short span of time in the economy.

Conversely, in the long run, the study documents a unidirectional causality from export to FDI. The non-existence of any long-run causality from FDI to export is due to the fact that though foreign investors are initially coming with the greed of high export opportunity, afterward they are mostly targeting the domestic market demand (Dash and Sharma 2011; Chakraborty et al. 2016). In practice, the investments in exportoriented sectors in India like food processing, beverages, chemicals (other than fertilizers), gems and jewelry, etc. which account for a large portion of foreign trade are given comparatively less emphasis. Apart from this, the highest level of FDI in India comes to the service sector $(62.47 \%$ of total FDI in the year 2016-2017 as per the Department of Industrial Policy and Promotion, Government of India) which has a very small contribution to the export of the country.

\section{Conclusions}

The present study is an endeavor to understand the dynamic relationship between FDI and foreign trade in the terms of export using a time-varying parameter model with vector autoregressive specification during the period of the first quarter of 1996-1997 to the last quarter of 2018-2019. The study reveals that FDI makes a significant contribution toward promoting the export of the Indian economy only in the short run whereas the export plays a vital role in promoting the inward flow of FDI in both the short run and long run. One of the important inferences that can be drawn from these findings is that the inward FDI has the potential to boost the export performance of the economy but there are some obvious reasons why this effect is not becoming sustainable in the long run. By examining the issue, we observe that one of the key reasons why the flow of FDI fails to exert a sustainable impact on export performance of the country is the lack of proper channelization of foreign funds to export-oriented industries of the economy. While in the case of China and other south-east Asian economies, the bulk of FDI is concentrated in the manufacturing sector, India's post-reform experience suggests that a substantial proportion of FDI has gone to the service sector which is the least contributor to the export of country (Kumar 2005 and Jana et al. 2019).

It is important to note that the service sector in India has been highly structured and organized. The sector is featured with high technology-base with utmost sophistication in operation, the involvement of trained and skilled labor, less dependency on the natural environment, short payback period on investments, etc. As a recent development, the Government of India under its mid-term review of Foreign Trade Policy (20152020) has increased incentives under Services Exports from India Scheme (SEIS) by 2\%. Moreover, the continuous efforts from the policymakers to remove many trade barriers to services make the sector much more attractive for foreign investors. 
At the same time, the government policy implications and efforts for channelizing FDI toward some selective industries like petroleum (which accounts for $15 \%$ of total exports), gems and jewelry (which accounts for $14 \%$ of total exports), textile (which accounts for $12 \%$ of total exports), etc. (Source: Department of Industrial Policy and Promotion, Government of India) which accounts for the highest exports from the country seem quite passive. According to Pradhan (2002), these passive implications and liberalization of the FDI policy merely considering the interests of local enterprises would not ensure long-term results.

\section{Policy recommendations}

As a part of policy recommendations, the researcher suggests that the short-run impact of FDI on export should be sustained for the long run, and policymakers should think about the lacunas that offset sustainability. In this regard, the study in line with Kumar (2005) also suggests the policymakers to learn lessons from the rewarding experiences of export-oriented FDI policy adopted by south-east Asian economies like China, Malaysia, Thailand and Korea and accordingly put forth policy directions toward improving the quality of FDI. More simply, the progressive dismantling of administrative barriers and strong channelization of FDI toward the export-oriented manufacturing sectors may prove to be a practical solution. Inviting multinational enterprises and transnational corporations as a source of FDI can also be fruitful because many times these enterprises are seen as instrumental to host countries manufactured export promotion (Kumar 1998; Lall and Narula 2004; Pradhan 2011). In addition, the government may also stipulate performance regulations, impose provisions like local sourcing of intermediate goods to intensify local linkages and export obligations to ensure the quality of FDI (Kumar and Pradhan 2002). Besides, a transparent economic system with stringent governance can play a key role in attracting more FDI (Siddharthan 2004). Moreover, in India, we observe that in the Foreign Trade Policy 2015-2020 the exports from SEZs have shown phenomenal growth. It is significantly higher than the overall export growth of the country (Source: Ministry of Commerce \& Industry, Government of India). Therefore, the government can also think of linking the FDI flow to SEZs and EPZs to further boost their export performance.

It is important to note that each and every research study has some limitations and the present empirical study is not an exception. Thus, the researchers admit that even after the highest possible efforts carried out to execute the study with adequate care and precision, still some noteworthy limitations exist. First, apart from FDI, export growth depends on a number of other economic variables and introducing such variables in modeling the relationship between FDI and foreign trade might concretize the study. Besides, the researchers also think that it is sensible to consider the structural break in the time series data to have a better understanding of the concerned relationship.

Acknowledgements

Not applicable.

Authors' contributions

Specification of contribution by the authors is not applicable to this research. The whole study is conducted with joint efforts. All authors read and approved the final manuscript.

Funding

Not applicable. 
Availability of data and materials

The datasets used and/or analyzed during the current study are available from the corresponding author on reasonable request.

\section{Competing interests}

The authors declare that they have no competing interests.

\section{Author details}

${ }^{1}$ Department of Commerce, Belda College, Paschim Midnapore, Belda, West Bengal 721 424, India. ${ }^{2}$ Department of Commerce, Vidyasagar University, Midnapore, West Bengal 721 102, India. ${ }^{3}$ Directorate of Distance Education, Vidyasagar University, Midnapore, West Bengal 721 102, India.

Received: 15 September 2019 Revised: 23 February 2020 Accepted: 11 April 2020

Published online: 18 April 2020

\section{References}

Andersen PS, Hainaut P (1998) Foreign direct investment and employment in the industrial countries. Working Paper No 61 Bank for International Settlements, pp 1-49

Barua R (2013) A study on the impact of FDI inflows on exports and growth of an economy: evidence from the context of Indian Economy. Res World J Arts Sci Commer 3(1):1-8

Bhatt PR (2013) Causal relationship between export, FDI and income: the case of Vietnam. Appl Econom Int Dev 13(1):161-176

Bojnec S, Ferto I (2014) Outward foreign direct investments and merchandise exports: the European ORCD countries. Rom J Econ Forecast 17(2):87-99

Chakraborty D, Mukherjee J, Lee J (2016) Do FDI inflows influence merchandise exports? Causality analysis on India over 1991-2016. Munich Personal RePEc Archive, pp 1-22

Dash RK, Sharma C (2011) FDI, trade, and growth dynamics: new evidence from the post-reform India. Int Trade J 25(2):233-265

Economic Survey (1991-1992) Ministry of Finance \& Company Affairs, Government of India, New Delhi

Engle RF, Granger CWJ (1987) Cointegration and error correction: representation estimation and testing. Econometrica 55(2):251-276

Enimola SS (2011) Foreign direct investment and export growth in Nigeria. J Econ Int Financ 3(11):586-594

Feder G (1982) On exports and economic growth. J Dev Econ 12(1-2):59-73

Granger CWJ (1969) Investigating causal relations by econometric models and cross spectral methods. Econometrica 37(3):424-438

Gulati U (1992) The foundations of rapid economic growth: the case of the four tigers. Am J Econ Sociol 51(2):161-172

Haq SG (2013) Impact of foreign direct investment on export: a case study of Pakistan. http://www.iises.net/download/ Soubory/soubory-puvodni/Haq.pdf. Accessed 09 Mar 2017

Harding T, Javorcik BS (2011) FDI and export upgrading. Discussion Paper Oxford University, ISSN 1471-0498

Harrison A (1996) Openness and growth: a time-series, cross-country analysis for developing countries. J Dev Econ 48(2):419-447

Hsiao FS, Hsiao MCW (2006) FDI, exports, and GDP in East and Southeast Asia-panel data versus time-series causality analyses. J Asian Econ 17(6):1082-1106

Jana SS, Sahu TN, Pandey KD (2017) Foreign direct investment and exports in India: some empirical insights. J Commer Manag Thought 8(4):684-702

Jana SS, Sahu TN, Pandey KD (2019) Foreign direct investment and economic growth in India: a sector-specific analysis. Asia-Pac J Manag Res Innov 15(1-2):53-67

Jhunjhunwala B (2002) Swadeshi vs. globalization. Financial Daily, The Hindu group of publications, Tuesday, Jul 30, 2002

Johansen S (1988) Statistical analysis of cointegrating vectors. J Econ Dyn Control 12(2):231-254

Jun KW, Singh H (1996) The determinant of foreign direct investment: new empirical evidence. Transnatl Corp 5(2):67-105

Keho Y (2015) Foreign direct investment, export and economic growth: some African evidences. J Appl Econ Bus Res 5(4):209-219

Kishore KG (2012) Econometric investigation of relationships among export, FDI and growth in India: an application of Toda-Yamamoto-Dolado-Lutkephol Granger causality test. J Dev Areas 46(2):231-248

Krueger AO (1990) Perspectives on trade and development. University of Chicago Press, Chicago

Kugler M (2006) Does foreign investment facilitate exports? Evidence from Venezuelan manufacturing, pp 1-32. https:// www.caf.com/media/3136/MauriceKugler,Doesforeinginvestmenfacilitateexports.pdf. Accessed 08 Mar 2017

Kumar N (1998) Multinational enterprises, regional economic integration, and export-platform production in the host countries: an empirical analysis for the US and Japanese corporations. Weltwirtschaftliches Archiv 134(3):450-483

Kumar N (2005) Liberalisation, foreign direct investment flows and development: Indian experience in the 1990s. Econ Polit Wkly 40(14):1459-1469

Kumar N, Pradhan JP (2002) Foreign direct investment, externalities and economic growth in developing countries: some empirical explorations and implications for WTO negotiations on investment. RIS Discussion Papers 27

Lall S, Narula R (2004) Foreign direct investment and its role in economic development: do we need a new agenda? Eur $J$ Dev Res 16(3):447-464

Li X, Chang HL, Su CW, Dai Y (2017) Does foreign direct investment promote exports in China? China Financ Rev Int 7(2):185-202 
Liu X, Burridge P, Sinclair PJ (2002) Relationships between economic growth, foreign direct investment and trade: evidence from China. Appl Econ 34(11):1433-1440

MacKinnon JG (1996) Numerical distribution functions for unit root and cointegration tests. J Appl Econom 11(6):601-618

MacKinnon JG, Haug AA, Michelis L (1999) Numerical distribution functions of likelihood ratio tests for cointegration. J Appl Econom 14(5):563-577

Mahmoodi M, Mahmoodi E (2016) Foreign direct investment, exports and economic growth: evidence from two panels of developing countries. Ekonomska Istrazivanja 29(1):938-949

Mainkhel AK, Thangavelu SM, Kalirajan K (2009) Foreign direct investment, export and economic growth in selected emerging countries: multivariate VAR analysis. http://papers.ssrn.com/sol3/Delivery.cfm/SSRN_ID1526387. Accessed 04 Mar 2017

Narula R, Dunning JH (2000) Industrial development, globalization and multinational enterprises: new realities for developing countries. Oxford Dev Stud 28(2):141-167

Pacheco-Lopez P (2005) Foreign direct investment, exports and imports in Mexico. World Econ 28(8):1157-1172

Pfaffermayar M (1996) Foreign outward direct investment and exports in Austrian manufacturing: substitutes or complements? Rev World Econ 132(3):501-522

Pradhan JP (2002) FDI spillovers and local productivity growth: evidence from Indian pharmaceutical industry. Artha Vijnana 44(3-4):317-332

Pradhan JP (2011) Foreign direct investment and development in India. Transnatl Corp Rev 3(2):1-6

Prasanna N (2010) Impact of foreign direct investment on export performance in India. J Soc Sci 24(1):65-71

Rasiah R, Gammeltoft P, Jiang Y (2010) Home government policies for outward FDI from emerging economies: lessons from Asia. Int J Emerg Mark 5(3-4):333-357

Sahu TN (2016) Macroeconomic variables and security prices in India during the liberalized period. Springer, Berlin

Sahu TN, Pandey KD (2018) Foreign direct investment and Indian economic growth. IIMS J Mana Sci 9(1):80-91

Sahu TN, Pandey KD (2020) Money supply and equity price movements during the liberalized period in India. Glob Bus $\operatorname{Rev} 21(1): 108-123$

Sahu TN, Mondal D, Bandopadhyay K (2013) Does oil price matter for Indian stock market? An empirical analysis. Appl Comput Financ Econom 247-261

Samsu SH, Derus AM, Ooi AY, Ghazali MF (2009) Causal links between foreign direct investment and exports: evidence from Malaysia. Int J Bus Manag 3(12):177-183

Sharma K (2000) Export growth in India: has FDI played a role Centre Discussion Paper No. 816

Siddharthan NS (2004) Business environment, investment climate and FDI: Chinese and Indian experiences. Econ Polit Wkly 39(36):3986-3988

Singh AB, Tandon P (2015) Causality between FDI inflows and export with reference to India: an analysis. IUP J Appl Econ 14(3):59-70

Sultan ZA (2013) A causal relationship between FDI inflows and export: the case of India. J Econ Sustain Dev 4(2):1-9

The World Bank: World Development Report 1987 (New York: Oxford University Press), pp 84-85

Trost M, Bojnec S (2016) Export-led growth: the case of the Slovenian and Estonian economies. Post-Communist Econ 28(3):373-383

Uddin MGS, Habib MW (2009) Causal relationship between foreign direct investment and export for Bangladesh: a time series analysis. Asian Econ Rev 51 (2):203-214

Zhang KH (2005) How does FDI affect a host country's exports performance? The case of China. In: International conference of WTO, China and the Asian economies, pp 25-26

Zhang Q, Felmingham B (2001) The relationship between inward direct foreign investment and China's provincial export trade. China Econ Rev 12(1):82-99

\section{Publisher's Note}

Springer Nature remains neutral with regard to jurisdictional claims in published maps and institutional affiliations.

\section{Submit your manuscript to a SpringerOpen ${ }^{\circ}$ journal and benefit from:}

- Convenient online submission

- Rigorous peer review

- Open access: articles freely available online

- High visibility within the field

- Retaining the copyright to your article

Submit your next manuscript at $\boldsymbol{\nabla}$ springeropen.com 